\title{
Are Investment Incentives Blunted by Changes in Prices of Capital Goods?
}

\author{
Kevin A. Hassett and R. Glenn Hubbard* \\ American Enterprise Institute; and Columbia University and the \\ National Bureau of Economic Research, respectively.
}

\begin{abstract}
Recent research on business investment decisions suggests that real investment in plant and equipment is quite sensitive to changes in the user cost of capital, pointing to the possibility that long-run changes in tax policy may have a significant impact on an economy's capital stock. Indeed, many countries have at times adopted investment tax incentives to stimulate investment. The prevalence of investment incentives suggests that local policy-makers believe these are effective in increasing investment at a reasonable cost in terms of lost revenue. In this paper, we explore this issue by estimating the extent to which countries are price-takers in the world market for capital goods. We find that most countries - even the United States - face a highly elastic supply of capital goods, suggesting that the effect of investment incentives on the price of investment goods is small. Hence effects of long-run changes in investment tax policy are likely to materialize in real investment rather than simply being dissipated in changes in capital-goods prices.
\end{abstract}

${ }^{*}$ We are grateful to Jose Campa, Austan Goolsbee, seminar participants at Columbia and the referee and editors for helpful comments and suggestions. Alex Brill provided excellent research assistance. 


\section{Introduction}

Most major developed countries have attempted at some point in the past 20 years to stimulate domestic fixed-capital formation with tax incentives for investment. Repeated adjustment of these incentives suggests that policymakers believe that they can be effective, and that they believe that investment incentives stimulate the quantity of fixed investment and not just the price of investment goods. Table 1 reveals that the 'tax wedge' for equipment investment (defined as 1 minus the rate of investment tax credit minus the corporate tax rate multiplied by the present value of depreciation deductions, all divided by 1 minus the corporate tax rate $)^{1}$ has varied significantly in recent years. In almost all countries, research on business investment decisions suggests that real investment is quite sensitive to changes in the user cost of capital, pointing out the possibility that long-run changes in tax policy may have a significant impact on the economy's capital stock. ${ }^{2}$ For example, Cummins, Hassett and Hubbard 1994 conclude that the elasticity of fixed investment with respect to the user cost of capital is about 0.6 , a result confirmed by Caballero, Engel and Haltiwanger 1995. This empirical consensus regarding

Table 1: Tax Wedge for Equipment Investment, 1981-92 (Sample of Industrialized Countries)

\begin{tabular}{lllllllllllll}
\hline & 1981 & 1982 & 1983 & 1984 & 1985 & 1986 & 1987 & 1988 & 1989 & 1990 & 1991 & 1992 \\
\hline Australia & 0.856 & 0.856 & 0.856 & 0.856 & 0.856 & 1.214 & 1.214 & 1.142 & 1.142 & 1.142 & 1.142 & 1.142 \\
Canada & 1.072 & 1.072 & 1.066 & 1.060 & 1.072 & 1.072 & 1.099 & 1.093 & 1.143 & 1.143 & 1.143 & 1.143 \\
Denmark & 1.148 & 1.148 & 1.148 & 1.148 & 1.222 & 1.222 & 1.222 & 1.222 & 1.222 & 1.148 & 1.136 & 1.136 \\
France & 1.022 & 0.922 & 1.222 & 1.222 & 1.222 & 1.182 & 1.182 & 1.161 & 1.142 & 1.131 & 1.114 & 1.114 \\
Germany & 1.283 & 1.283 & 1.283 & 1.283 & 1.283 & 1.283 & 1.283 & 1.283 & 1.283 & 1.222 & 1.240 & 1.240 \\
Ireland & 1.182 & 1.222 & 1.222 & 1.222 & 1.222 & 1.222 & 1.222 & 1.197 & 1.168 & 1.168 & 1.148 & 1.148 \\
Italy & 1.127 & 1.156 & 1.156 & 1.192 & 1.192 & 1.192 & 1.192 & 1.192 & 1.192 & 1.192 & 1.203 & 1.274 \\
Japan & 1.161 & 1.161 & 1.161 & 1.170 & 1.170 & 1.170 & 1.161 & 1.161 & 1.148 & 1.133 & 1.139 & 1.139 \\
Netherlands & 0.974 & 0.974 & 0.974 & 0.948 & 0.948 & 0.945 & 0.945 & 1.161 & 1.120 & 1.120 & 1.120 & 1.120 \\
Sweden & 1.069 & 1.069 & 1.069 & 1.241 & 1.241 & 1.241 & 1.241 & 1.241 & 1.241 & 1.148 & 1.095 & 1.095 \\
Switzerland & 1.024 & 1.024 & 1.024 & 1.024 & 1.024 & 1.024 & 1.024 & 1.024 & 1.024 & 1.024 & 1.024 & 1.024 \\
UK & 1.241 & 1.241 & 1.241 & 1.182 & 1.148 & 1.120 & 1.120 & 1.120 & 1.120 & 1.120 & 1.109 & 1.109 \\
US & 0.942 & 0.941 & 0.960 & 0.965 & 0.955 & 1.083 & 1.097 & 1.076 & 1.076 & 1.076 & 1.076 & 1.076 \\
\hline
\end{tabular}

Sources: Cummins, Harris and Hassett 1995, Tables 7.1, 7.2, and (for the last row) Goolsbee 1998.

\footnotetext{
${ }^{1}$ This is the familiar tax wedge in the Jorgensonian user cost of capital.

${ }^{2}$ See Hassett and Hubbard 1997.
} 
long-run effects of tax policy on investment comes at a time when both economists and policy-makers in industrialized countries are paying more attention to determinants of long-term economic growth.

While recent empirical research suggests an emerging consensus that real fixed investment is very responsive over the long run to changes in the tax treatment of investment (through investment tax credits, depreciation allowances and profit taxes), an important question remains for policymakers: in the short run, by how much do investment incentives raise the price as opposed to the quantity - of capital goods? If, for example, the quantity of capital goods in the economy were fixed in the short run, the increase in demand for capital goods as a result of an investment incentive would bid up the price of machines, with no effect on output in the capital-goods sector. In other words, the value of investment would increase, but not the quantity of new capital goods, the objective of the investment incentive. More generally, it may be that if domestic capital-goods sellers have market power, some portion of the demand stimulus provided by the investment incentive would raise domestic prices of capital goods. Alternatively, one might argue that domestic capital-goods manufacturers face a sharply upward-sloping marginal cost schedule for producing capital goods. In this case, a tax-induced increase in demand would increase the cost - and price - of capital goods.

By contrast, one scenario in which tax credits might have an especially large impact on the quantity of investment without dissipation in prices of investment goods, is one in which firms' demand for capital is responsive to changes in the user cost of capital, and in which capital goods are supplied perfectly elastically. It is implausible that the supply function for most individual capital-goods manufacturers is highly elastic, given their high capital intensity. The effective supply of capital goods to a given domestic market, however, might well be elastic if the world market for capital goods is perfectly competitive and open. That is, even if US manufacturers of capital goods faced rising marginal costs of production, an open world market for capital goods could provide imported capital goods with smaller or no capital-goods price increases.

To date, there is little evidence concerning the openness of the world market for capital goods. The empirical literature on financial capital mobility begins with Feldstein and Horioka 1980, who first documented the fact that there is nearly a 1:1 correlation between changes in national saving and domestic fixed investment; many subsequent studies have demonstrated the robustness of this finding.

Even if investment funds are apparently imperfectly mobile, however, this does not necessarily imply that capital goods are not very mobile. Indeed, for most of the past 30 years, the empirical literature relating taxes to investment through the user cost of capital has assumed that firms are price-takers in 
the market for capital goods. ${ }^{3}$ This assumption simplifies empirical work significantly: if the price of capital goods were set in world markets, one might ignore the response of the price of capital goods to tax policy, and estimation of the parameters of the investment-demand function would not be obscured by this source of simultaneity problems. Because these studies have explored the responsiveness of real investment under a scenario of perfectly elastic supply, an upward-sloping supply curve would imply even higher elasticities of investment demand with respect to tax changes than are reported.

The assumption that firms are price-takers in the market for capital goods has not, until recently, been considered controversial, perhaps because imports and exports of capital goods make up a large proportion of world trade. For example, as can be seen in Figure 1, in the United States, imports of capital goods accounted for around $10 \%$ of aggregate investment in the early 1970s, climbing to above $45 \%$ by 1995 . Over the same time-period, US exports of capital goods experienced a similar boom. Such flows may be the natural outcome of competition in world markets. Protectionism toward capital goods is very different from protectionism toward butter, for example. Countries which use trade barriers to restrict purchases of foreign-capital goods run the risk of undermining the competitiveness of their firms.

Rather than rely on such stylized facts, Goolsbee 1998 recently explored the link between investment tax policy and capital-goods prices, and found that US prices for capital goods appear to respond to investment incentives. His result has support in the empirical international economics literature, where 'purchasing power parity' is often rejected. ${ }^{4}$

In this paper, we shed new light on this issue by identifying and testing equilibrium conditions that must hold if the world market for capital goods is open (in the sense that protectionist measures do not limit the responsiveness of capital-goods output to tax-induced shocks to the demand for capital goods). We first explore the extent to which the price of capital goods is similar across countries. Another way in which we pursue this issue is to address specifically the extent to which local tax policy affects prices of capital goods. If all countries are small relative to the world market for capital goods, no local policy shock will have any impact on the world price for capital goods. If capital is mobile, all countries might increase their investment in a country adopting an investment incentive. In this case, the condition that a country is 'small' translates into the condition that the total investment from all sources in a given country is itself small, relative to the world output of capital goods; at the same time, increases in investment incentives in any given country that

\footnotetext{
${ }^{3}$ See, for example, Jorgenson 1963; Hall and Jorgenson 1967; Auerbach and Hassett 1991; and Cummins, Hassett and Hubbard 1994, 1996.
}

${ }^{4}$ See, for example, Bordo and Choudhry 1976; Kravis and Lipsey 1971, 1977, 1978; and Officer 1986. 

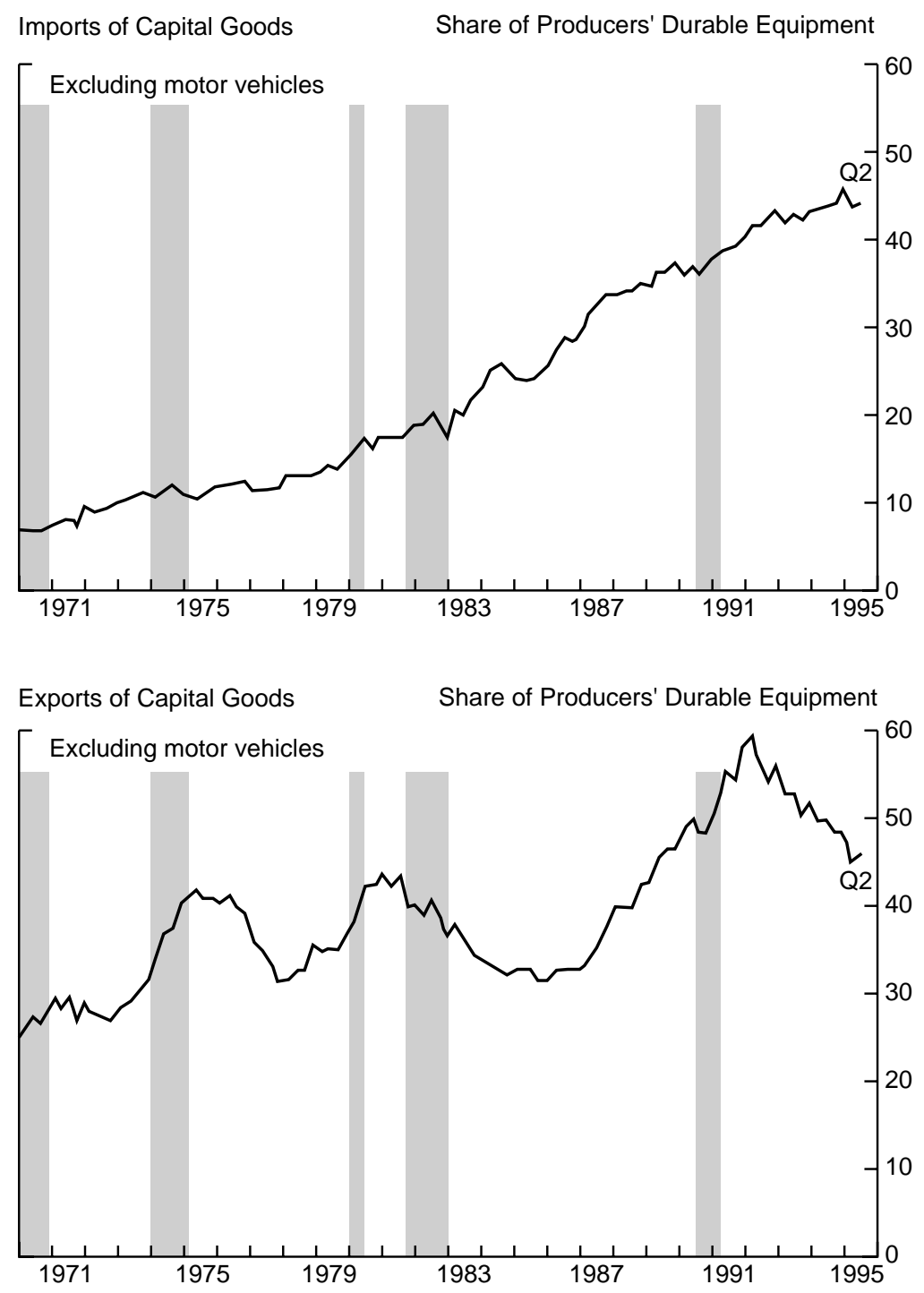

Figure 1: US Imports and Exports of Capital Goods (measured in 1987 dollars)

stimulate domestic investment in any given country are assumed not to lead to higher prices for capital goods. ${ }^{5}$ We consider this prediction both for capital-goods prices across countries and for a sample of capital goods (facing different tax treatment across assets and over time) for the United States.

We describe our empirical approach and specific tests in Section II. In Section III, we describe the data we use for our cross-country and cross-asset

${ }^{5}$ See Hassett and Hubbard 1997. 
(for the United States) tests in our analysis. Our empirical results are presented in Section IV. In Section V, we set out our conclusions and offer observations for the broader debate about effectiveness of tax policy toward investment.

\section{Testing Tax Effects on Capital-Goods Prices Across Countries}

We begin our analysis from the perspective of the 'law of one price'. For goods that are tradable, the law of one price states that there is a single price of a tradable good, no matter where that good is produced, where the prices of the good in individual countries are stated in a common currency using market exchange rates. Putting aside aggregation-related index-number problems, one can extend the law of one price for a single tradable good to a class of tradable goods. ${ }^{6}$ In our case, we consider capital goods and their prices. ${ }^{7}$

A sufficient condition for the law of one price for a group of tradable goods to be valid is that markets be competitive (in the Chamberlinian sense). If the tradable goods (or, in our case, capital goods) in a market are not literally identical, then, for the law of one price to be valid approximately, elasticities of substitution among goods in production and consumption must be high. ${ }^{8}$

If the market for capital goods is open and perfectly competitive, and transportation costs are negligible, all countries should pay the same price for machines. Letting $q$ be the price of capital goods in a common currency, $t$ be the time index, and $i$ and $j$ refer to any two arbitrary countries, then assuming that all countries use the same bundle of capital goods - at each time, $t$, the following must hold: ${ }^{9}$

$$
q_{i, t}=q_{j, t} \forall i, j
$$

If equation (1) did not hold, arbitrage would be possible. In practice, exchange-rate fluctuations, adjustment costs and delivery expenses may cause

\footnotetext{
${ }^{6}$ Extending the law of one price to all goods - as opposed to just tradable goods - is more difficult; one must argue further that, for any given country, the price level of tradable goods is equal to the price level for non-tradable goods.

${ }^{7}$ Evidence for the law of one price at the level of aggregate tradable goods is mixed - see, for example, Kravis and Lipsey 1978, and Officer 1986.

${ }^{8}$ Market power for capital-goods producers can lead the law of one price to fail because of, for example, price discrimination across markets or strategic pricing decisions.

${ }^{9}$ See also the more general description in Officer 1986.
} 
observed prices to differ across countries at times. In this case, however, a 'weak law of one price' holds:

$$
q_{i, t}=\alpha+\beta \star q_{j, t}+\varepsilon_{i, t}
$$

where $\beta=1, \varepsilon$ is a white-noise error term, and $\alpha$ - which may reflect transportation costs - is small and varies from country to country. The error term results from errors in the measurement of prices due to unobserved compositional shocks that vary between countries. Our first test, using capital-goods prices from many countries, is based on equation (2).

Exploiting equation (2) as a test of the law of one price requires several assumptions, however. Under the null hypothesis, the equation holds across all countries and prices, so the hypothesis can be tested by choosing a 'base' country, $j$, with price as $q_{j, t}$ and constructing a system of equations with a separate equation for each country other than the base country. Thus, if we have $N$ countries, we have a system of $N-1$ equations relating the capitalgoods price for each country to the capital-goods price for the base country. We can then estimate equation (2) using standard panel data techniques, wherein we can allow for country effects in the model. Under the null hypothesis, each country takes the world price as given exogenously. As discussed below, our results are not sensitive either to the choice of common currency or the choice of base country.

Economic theory offers no unambiguous guidance about the source of the error term. As a consequence, for sensitivity analysis, we estimate equation (2) under a number of alternative specifications that are consistent with equation (1). Towards this end, we estimate equation (2) with and without taking logarithms of the variables, and with and without country-fixed effects. ${ }^{10}$

As we noted in the introduction, there is an alternative way to test for the validity of our hypothesis that capital-goods prices are equivalent across countries. The price-taking assumption provides a test of effects of investment incentives on capital-goods prices (i.e. the product of the corporate income tax and the present value of depreciation allowances on an investment of one currency unit). Thus we can evaluate the orthogonality condition:

$$
q_{t} \perp\left[T A X_{j}, E T A X_{1}\right], \forall(j \leqslant t, 1>t)
$$

where TAX is 1 minus the sum of the rate of investment tax credit and the value of depreciation allowances divided by 1 minus the tax rate, and $E$ is the expectations operator, conditional on the information set at time $t$. This

\footnotetext{
${ }^{10} \mathrm{We}$ also estimated our equations in first-differences; estimates were similar to those from the country-fixed effects runs, and we exclude them here.
} 
condition is two-sided. If firms construct their expectations of future tax variables using only data available to the econometrician at time $t$, and the time-series process for TAX follows some stationary, autoregressive process, then a test of equation (3) would be a standard Granger-causality test assuming, of course, that the policy variable is independent of world businesscycle variables that might be expected to interact with the world price level. Because even current-period shocks can be of no value in predicting price movements, we perform this test below with both current and lagged tax variables. Because tax policy may be related to world economic conditions, failure to find any effect of local policy on prices would be strong evidence of open markets.

We conduct this second test in two ways. First, using a multi-country data set, we explore whether a local investment tax-wedge change in any of our countries affects the prices paid for capital goods in that country. If the shortrun supply curve for capital goods is upward-sloping, TAX should have a significant negative coefficient. For our second test, we use disaggregated data on asset-specific investment prices and tax variables for the United States to explore whether US tax policy has had any effect on the extra price paid for investment. We provide this second test because a conclusion that the United States is too small to affect the world price of capital goods is especially meaningful, given the relative size of the country, which, as we show in Figure 2, accounted for roughly $21 \%$ of world investment in 1992.

The capital-goods price deflators are non-stationary; given the low dimensionality of the cross-section in our sample, this non-stationarity may lead to spurious inferences. This presents no problem in our tests for the equality of capital-goods prices under the null hypothesis, but may be problematic when we analyse tax terms. To control for this possibility, we first-difference the capital-goods price variables in order to make them stationary before constructing our panel estimates of the responsiveness of prices to changes in local tax policy. In our final set of estimates, which focus only on US data, the time period is sufficiently long for us to estimate time-series models, as well as to pool the data in order to allow us to address issues of non-stationarity and co-integration directly.

Finally, we do not claim to identify the supply curve for capital goods with our second set of tests; it is difficult to conceive of instrumental variables that would make possible separate identification of the demand and supply curves. One would expect that the estimated tax coefficients in our test would also be zero - irrespective of the slope of the supply curve - if demand does not respond to tax variables. However, if one accepts findings that observed real investment responds to tax variables, (as, for example, in Cummins, Hassett, and Hubbard 1994, 1996), then our zero estimated coefficient is perhaps best explained by a highly elastic local supply curve. One might nonetheless 


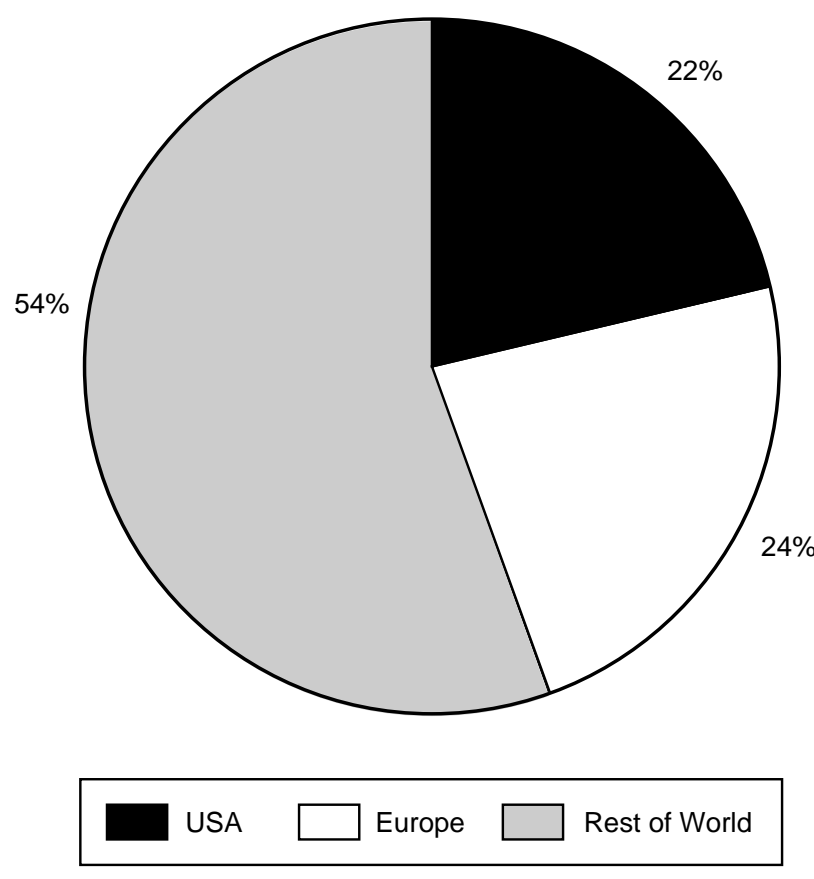

Source: Penn World Tables, Mark 5.6

Figure 2: Share of World Investment by Country, 1992

argue that the price does not respond to investment tax credits because both the supply and demand curves shift outwards when investment incentives are introduced. In any case, these identification issues highlight the important complementarity between our two sets of tests. If the evidence is strong that the law of one price holds for capital goods, this helps us interpret the result that local tax variables do not impact on local capital-goods prices.

\section{The Data}

We use two data sets in our various tests. The first includes deflators for producers' durable equipment and investment incentives for 12 countries: Australia, Denmark, France, Germany, Ireland, Italy, Japan, the Netherlands, Switzerland, Sweden, the United Kingdom and the United States. We focus only on industrialized countries because our test is valid only under the assumption that the deflator used is measuring a similar concept of investment in each country. Among industrialized countries, we restrict the sample to this set of countries because of data availability and because of our desire to have a long and balanced panel. 
The capital-goods price data we use are taken from the OECD publication National Income Accounts, and cover the sample period from 1971 to 1992. The price deflators for producers' durable equipment are collected by the OECD from the individual countries. This data-collection process entails both a benefit and a cost for our study. The benefit is that the independent calculation of the series lowers the risk that the law of one price will hold by construction. The cost is that the exact definition of each deflator may be different, which may invalidate our test. The latter may be especially important when comparing price deflators to those in the United States, which is the only country that attempts to adjust its price deflators hedonically for technological improvement. Because of this adjustment, the price deflator for the United States, which includes a substantial adjustment for the evolution of computer prices, may not align well with the others, which are closer to transaction prices. As a check for this possibility, we provide results both with and without the United States, but any anomalous results for the United States should be interpreted with caution.

Price deflators are normalized for each country to equal unity in 1987 . We convert deflators into dollar terms using data on bilateral exchange rates. We then renormalize the new common-currency price deflators to equal unity for each country in 1987, effectively imposing the law of one price in that year. The logarithmic results, which relegate these normalizations to the constant term, provide a check on whether the particular normalization we choose influences the results.

Our international tax data (presented in Table 1) cover the years from 1981 to 1992, and are taken from Cummins, Harris and Hassett 1995. In theory, orthogonality of domestic tax parameters extends to all domestic tax variables, including domestic depreciation rules as well as investment tax credits, so we use the total tax wedge for equipment investment as our tax variable. In order to focus purely on tax effects, we construct the present value of depreciation deductions for each country other than the United States by assuming that the depreciation rate is 0.14 and the real discount rate is 0.04 . For the United States, we take the tax wedge from Goolsbee 1998.

Our second data set contains information on prices and the tax treatment of 22 different types of investment assets only for the United States, for the years from 1960 to 1989 . For comparability to previous work, we use the price and tax variables also used by Goolsbee 1998.

\section{Incentives and Capital-Goods Prices: Findings}

This section reports our results in three subsections. In subsection A we report results from the capital-goods price regressions described in Section II. In 
subsection B we describe cross-country evidence on the effects of local tax shocks on capital-goods prices. In subsection $\mathrm{C}$, we focus on results for the disaggregated data from the United States.

\section{A. The Law of One Price for Capital-Goods Prices}

Table 2 reports the results of pooled estimation of equation (2) for the countries in our sample. The first row presents the results for all countries. The estimated coefficient on the price of capital goods in the base country (Denmark) is approximately unity, with a small standard error. The next two models reported first exclude the United States, and second focus on only the European countries in our sample. For each of these models, the estimated coefficient on the base-country capital-goods price deflator is very close to unity, again with a small standard error. The next row reports the results for the United States alone. This time the estimated coefficient is significantly less than unity, indicating either that parity does not hold for the United States in practice, or that the US deflator's hedonic adjustment invalidates the test for

\section{Table 2: Test of Equality of Capital-Goods Prices (Cross-National Panel Data, Levels)}

Dependent Variable: Country-Specific Capital-Goods Price Deflator No Country-Fixed Effects

\begin{tabular}{|c|c|c|c|c|}
\hline Sample & Constant & $\mathrm{q}$ (Denmark) & No. Obs. & $\overline{\mathrm{R}}^{2}$ \\
\hline All & $\begin{array}{c}0.009 \\
(0.015)\end{array}$ & $\begin{array}{c}1.004 \\
(0.018)\end{array}$ & 264 & 0.893 \\
\hline All except US & $\begin{array}{c}-0.019 \\
(0.014)\end{array}$ & $\begin{array}{c}1.033 \\
(0.016)\end{array}$ & 242 & 0.920 \\
\hline Europe & $\begin{array}{c}0.013 \\
(0.009)\end{array}$ & $\begin{array}{c}1.018 \\
(0.011)\end{array}$ & 198 & 0.96 \\
\hline US & $\begin{array}{c}0.313 \\
(0.080)\end{array}$ & $\begin{array}{c}0.680 \\
(0.091)\end{array}$ & 22 & 0.65 \\
\hline All $^{1}$ & $\begin{array}{c}0.012 \\
(0.011)\end{array}$ & $\begin{array}{c}1.025 \\
(0.036)\end{array}$ & 264 & 0.83 \\
\hline All except US ${ }^{1}$ & $\begin{array}{c}0.012 \\
(0.010)\end{array}$ & $\begin{array}{c}1.055 \\
(0.037)\end{array}$ & 242 & 0.85 \\
\hline Europe $^{1}$ & $\begin{array}{c}0.028 \\
(0.006)\end{array}$ & $\begin{array}{c}0.987 \\
(0.013)\end{array}$ & 198 & 0.96 \\
\hline US $^{1}$ & $\begin{array}{c}0.011 \\
(0.035)\end{array}$ & $\begin{array}{c}0.692 \\
(0.060)\end{array}$ & 22 & 0.75 \\
\hline
\end{tabular}

Notes: Heteroskedasticity-consistent standard errors are in parentheses. ${ }^{1}$ Variables are in natural logarithms. 
Table 3: Test of Equality of Capital-Goods Prices (Cross-National Panel Data, First Differences)

Country-Fixed Effects

(all variables in logs)

\begin{tabular}{lcll}
\hline Sample & q (base country) & No. Obs. & $\overline{\mathrm{R}}^{2}$ \\
\hline All & 1.025 & 264 & 0.91 \\
& $(0.023)$ & & \\
All except US & 1.054 & 242 & 0.96 \\
& $(0.026)$ & 198 & 0.97 \\
Europe & 0.987 & & \\
& $(0.011)$ & & \\
\hline
\end{tabular}

Note: Heteroskedasticity-consistent standard errors are in parentheses.

the United States. The next four models modify the first specifications by using the logarithm of, rather than the level of, the dependent and independent variables. The results are qualitatively similar to the level specifications, with a precisely estimated coefficient on the base-country capital-goods price variable close to unity. ${ }^{11}$

Table 3 reports the full-sample results of estimating equation (2) with country fixed effects; for brevity we report only the results from using the variables in logarithms. We cannot reject the hypothesis that capital-goods prices in all countries are equal. Table 4 repeats the estimation using two other countries - Italy and the Netherlands - as the base country. We find essentially the same results, with parity holding for all countries except the United States, when we use the Netherlands or Italy as the base country. ${ }^{12}$

We cannot say whether the low estimated value of coefficient for the United States reflects the fact that the US market is not 'small and open', or whether it reflects the fact that the US capital-goods price deflator includes a hedonic adjustment not included in the others. If the hedonic adjustment is important, this test is not appropriate for the US data. However, the second test we proposed in Section II potentially sheds light on this issue. If the United States is a large player in the world market for capital goods, investment tax policy in the United States may affect the prices paid by other countries for capital goods.

\footnotetext{
${ }^{11}$ The residuals in the pooled runs excluding the United States do not reveal high serial correlation, whereas the US residual does. These data are available from the authors on request.

${ }^{12}$ The results change significantly only when the United States is used as the base country.
} 
Table 4: Test of Equality of Capital-Goods Prices (Cross-National Panel Data, Other Base Countries)

(all variables in logs)

\begin{tabular}{|c|c|c|c|c|c|}
\hline Sample & Base Country & Constant & $\mathrm{q}$ (base country) & No. Obs. & $\overline{\mathrm{R}}^{2}$ \\
\hline All & Netherlands & $\begin{array}{c}-0.006 \\
(0.010)\end{array}$ & $\begin{array}{c}1.040 \\
(0.037)\end{array}$ & 264 & 0.836 \\
\hline All except US & Netherlands & $\begin{array}{c}-0.007 \\
(0.010)\end{array}$ & $\begin{array}{c}1.070 \\
(0.038)\end{array}$ & 242 & 0.85 \\
\hline Europe & Netherlands & $\begin{array}{c}0.011 \\
(0.006)\end{array}$ & $\begin{array}{c}1.002 \\
(0.013)\end{array}$ & 198 & 0.965 \\
\hline US & Netherlands & $\begin{array}{c}0.002 \\
(0.035)\end{array}$ & $\begin{array}{c}0.711 \\
(0.056)\end{array}$ & 22 & 0.77 \\
\hline All & Italy & $\begin{array}{c}0.008 \\
(0.010)\end{array}$ & $\begin{array}{c}1.012 \\
(0.034)\end{array}$ & 264 & 0.838 \\
\hline All except US & Italy & $\begin{array}{c}0.007 \\
(0.035)\end{array}$ & $\begin{array}{c}1.041 \\
(0.009)\end{array}$ & 242 & 0.850 \\
\hline Europe & Italy & $\begin{array}{c}0.022 \\
(0.006)\end{array}$ & $\begin{array}{c}0.972 \\
(0.014)\end{array}$ & 198 & 0.960 \\
\hline US & Italy & 0.016 & 0.703 & 22 & 0.801 \\
\hline
\end{tabular}

Note: Heteroskedasticity-consistent standard errors are in parentheses.

\section{Table 5: Investment Incentives and Capital-Goods Prices (Cross-National Panel Data)}

Dependent Variable: Country-Specific Log Difference of the Capital-Goods Price Deflator

\begin{tabular}{lccclll}
\hline Fixed Effects? & Constant & Trend & TAX & TAX lagged & No. Obs. & $\overline{\mathrm{R}}^{2}$ \\
\hline no & -21.95 & 0.011 & 0.00006 & & 144 & 0.116 \\
& $(3.738)$ & $(0.002)$ & $(0.0002)$ & & & \\
no & -14.761 & 0.007 & 0.95 & -0.091 & 132 & 0.056 \\
& $(4.138)$ & $(0.002)$ & $(0.117)$ & $(0.116)$ & & \\
yes & - & 0.011 & -0.004 & - & 144 & 0.130 \\
& & $(0.002)$ & $(0.053)$ & & & \\
yes & - & 0.008 & -0.110 & 0.115 & 132 & 0.084 \\
& & $(0.002)$ & $(0.120)$ & $(0.129)$ & & \\
\hline
\end{tabular}

Notes: Heteroskedasticity-consistent standard errors are in parentheses.

\section{B. Local Effects of Policy: Evidence}

In Table 5, we provide the results of our tests for impacts of local tax policy on the prices paid for capital goods. The dependent variable is the log difference of the capital-goods price variable. The first row reports the result when we do 
not control for fixed effects. The estimated coefficient on the tax variable is almost exactly zero. The subsequent rows indicate that allowing for a lagged response does not produce a significant tax effect, nor does controlling for fixed effects. Thus Table 5 does not contradict the conclusions implied by the previous three tables. There is no evidence that investment policy in individual countries has a significant impact on the price paid for capital goods in those countries.

It is possible, however, that these results give a false impression. Because our approach employs a pooled, panel-data estimator, it implicitly assumes that the effect of local tax policy on the price paid for investment goods in the United States is the same as the effect of local tax policy on the price paid for investment goods in, for example, France. It may be that the (plausibly zero) coefficients in smaller countries 'drown out' the impact of US changes. Given the limitations of the data used in this subsection, exploring results on a country-by-country basis is not feasible. In the next subsection, we turn to results of the same specifications using a much larger disaggregated US assetclass data set that allows us to explore the time-series responsiveness of the price variables to the tax variables more precisely.

\section{US Tax Policy and Capital-Goods Prices}

In this subsection, we continue to investigate the impact of local tax policy on capital-goods prices, but this time we focus only on US data. Our tax variable is an asset-specific measure of the tax variable that enters the traditional usercost calculation; 1 minus the rate of investment tax credit minus the present value of depreciation deductions multiplied by the corporate tax rate, all divided by 1 minus the corporate tax rate ('TAX' in the tables). If the supply curve for capital goods were upward-sloping, the estimated coefficient on this variable should be negative. In this data set, the longer time period - 31 years - allows us to explore the impact on each asset separately, although we will investigate the results of pooled regressions in subsequent tables. In Table 6, we provide summary statistics that describe the time-series properties of each series. In the first and second columns, we report augmented Dickey-Fuller statistics for the null hypothesis that each series is non-stationary of order one $(I(1))$. For the tests we report, the Dickey-Fuller regression included two lags of the change in the dependent variable, along with a constant term. The 5\% MacKinnon critical values are reported in the last row of the table. Each of the price and tax variables is non-stationary, with no Dickey-Fuller statistic approaching the MacKinnon critical value. (Although not reported, the results are not changed if we include a trend term in the Dickey-Fuller regression.) 
Given that each of our variables is non-stationary, one would expect them to be co-integrated if the long-run supply curve for capital goods were upward-sloping. In the third column, we report the co-integrating regressions for each variable. There is no evidence that any of the error terms in the cointegrating equations is stationary.

While the evidence based on co-integration tests suggest that there is no long-run relationship between investment tax variables and capital-goods prices, it may be that prices respond in the very short run to tax policy but that, ultimately, supply response reverses the short-run supply effect. To investigate this possibility, we performed Granger-causality tests of the null hypothesis that the first-difference of the capital-goods price is not Grangercaused by the first difference of the tax variable for each of our assets, with the results reported in the fourth column of Table 6. Again, the evidence that taxes

Table 6: US Data on Capital-Goods Prices and Investment Incentives, Descriptive Statistics

\begin{tabular}{|c|c|c|c|c|c|}
\hline & \multicolumn{2}{|c|}{$\begin{array}{l}\text { Dickey-Fuller } \\
\text { Statistics }\end{array}$} & \multirow{2}{*}{$\begin{array}{l}\text { Dickey-Fuller } \\
\text { Statistics } \\
\text { Cointegrated? }\end{array}$} & \multicolumn{2}{|c|}{$\begin{array}{l}\text { F statistic (p-value): } \\
\text { Price not Granger-causec } \\
\text { by Tax }\end{array}$} \\
\hline & Price & Tax & & & \\
\hline Furniture & -2.16 & -1.70 & -2.03 & 0.79 & $(0.46)$ \\
\hline Fabricated Metals & -2.45 & -1.53 & -2.46 & 0.14 & $(0.87)$ \\
\hline Engines & -1.36 & -1.66 & -2.23 & 0.62 & $(0.55)$ \\
\hline Tractors & -0.96 & -1.52 & -0.90 & 2.29 & $(0.13)$ \\
\hline Agricultural Machinery & -1.71 & -1.70 & -1.89 & $2.85^{\star \star}$ & $(0.01)$ \\
\hline Construction Machinery & -0.80 & -1.68 & -1.22 & 0.88 & $(0.43)$ \\
\hline Mining Machinery & -1.16 & -1.69 & -1.14 & 0.52 & $(0.60)$ \\
\hline Metalwork Machinery & -1.57 & -1.72 & -2.27 & 2.43 & $(0.11)$ \\
\hline Special Industrial Machinery & -0.44 & -1.75 & -1.22 & 2.41 & $(0.11)$ \\
\hline General Industrial Machinery & -1.31 & -1.70 & -2.34 & 1.77 & $(0.19)$ \\
\hline Office and Computer Machinery & -0.20 & -1.76 & 0.38 & 0.33 & $(0.72)$ \\
\hline Service Industry Machinery & -1.19 & -1.74 & -1.26 & 0.26 & $(0.78)$ \\
\hline Electrical Distribution & -2.25 & -1.58 & -2.18 & 0.11 & $(0.89)$ \\
\hline Communication & -0.44 & -1.58 & -1.06 & 1.16 & $(0.33)$ \\
\hline Electrical Equipment & -1.94 & -1.58 & -2.01 & 1.07 & $(0.36)$ \\
\hline Trucks and Buses & -2.29 & -1.69 & -2.09 & 1.82 & $(0.18)$ \\
\hline Automobiles & -2.02 & -1.59 & -0.95 & 0.62 & $(0.55)$ \\
\hline Aircraft & -2.33 & -1.43 & -2.46 & 0.64 & $(0.54)$ \\
\hline Ships & -1.47 & -1.71 & -1.59 & 0.84 & $(0.44)$ \\
\hline Railway Equipment & -1.56 & -1.65 & -1.91 & 0.38 & $(0.69)$ \\
\hline Instruments & 0.31 & -1.63 & -0.53 & 0.36 & $(0.70)$ \\
\hline Other Equipment & -1.02 & -1.76 & -1.68 & 0.29 & $(0.75)$ \\
\hline Note: MacKinnon $5 \%$ critical value & -2.97 & -2.97 & -3.58 & & \\
\hline
\end{tabular}

Source: Authors' calculations. 
affect prices is very weak. In only one case (agricultural machinery) is there clear evidence of Granger-causality - about the number of rejections one would expect, given the size of our tests. Thus the evidence supports our earlier conclusion that there is no relationship between capital-goods prices and taxes, and that the world market for capital goods appears to be open.

As we noted earlier, Goolsbee 1998 offers evidence for the United States that investment incentives have a statistically significant and economically important effect on prices, with prices increasing whenever investment tax credits were introduced. In Table II of his paper, he reports estimated tax coefficients for the 22 assets in our Table 6 - using the same data we use - that almost always find a significant role for tax policy in explaining prices. Indeed, Goolsbee argues that an investment tax credit of $10 \%$ in the United States would increase equipment-goods prices by $7 \%$, with prices remaining higher (relative to the no-incentive case) for a very long period of time - possibly even forever. It is useful to put this result in perspective. If the elasticity of US real investment with respect to the user cost is -0.6 , introducing an investment tax credit of $10 \%$ (thereby reducing the user cost of capital by about 10\%) would increase US investment demand by about $6 \%$. Because the United States accounts for about $21 \%$ of world investment demand, this would rise by about $0.21 \times 0.06$, or about $1.2 \%$. Hence, according to Goolsbee's estimate, an increase in world demand for capital goods of about $1.2 \%$ increases the price of capital goods by $7 \%$, perhaps forever. If capacity utilization around the world were about equal to that in the United States (0.81 in 1997), this would represent an increase in world demand equal to around $6 \%$ of unutilized world productive capacity.

Fortunately, we can explain why Goolsbee reaches such a different conclusion from that which we reach here. Our Tables 7 and 8 help to identify the causes of the disagreement. In the first column of Table 7, we report the results of pooling each of the assets together (ignoring, for a moment, issues of nonstationarity) and regressing the level of price on the level of the tax variable (as well as on a dummy variable for the Nixon price controls, a time trend and the level of real GDP). ${ }^{13}$ Following Goolsbee, we also employ in these two tables a correction for second-order serial correlation. Here, as in Goolsbee's Table II, the estimated tax coefficient is negative and statistically significantly different from zero, indicating that prices of capital goods rise when tax policy favours business fixed investment.

\footnotetext{
${ }^{13}$ Goolsbee also included exchange rates in the equation, data which he also kindly supplied to us. We found that including these variables did not alter the results substantively, but complicated the issues of non-stationarity. We opted to exclude them in the interest of brevity. Regressions including the exchange-rate data are available upon request.
} 
Table 7: Investment Incentives and Capital-Goods Prices, US Assets

\begin{tabular}{lcc}
\hline & \multicolumn{2}{c}{ Dependent Variable } \\
\cline { 2 - 3 } Independent Variable & Price & Change in Price \\
\hline Constant & 0.800 & -0.013 \\
\multirow{2}{*}{ TAX } & 0.014 & 0.002 \\
& -0.190 & - \\
$\Delta$ TAX & 0.013 & -0.001 \\
GDP & - & 0.008 \\
& & \\
$\Delta$ GDP & -0.001 & -0.003 \\
Nixon dummy & 0.0004 & 0.0002 \\
Time trend & & -0.004 \\
& -0.066 & 0.002 \\
Number of observations & 0.005 & -0.001 \\
& -0.010 & 0.00001 \\
\end{tabular}

Because in this data set the cross-sectional dimension is approximately equal to the time-series dimension, the pooled regression may reflect well-known spurious regression problems. There are two signals that this might be the case. First, there is significant residual serial correlation, indicating that the single second-order correction applied to each series does not allow adequately for heterogeneity. Second, the estimated coefficients do not tell a consistent story. For example, the estimated coefficient on GDP, the only variable Goolsbee chose to include in log-differenced form, is negative. Because expenditures on capital goods are cyclical, one would expect that capital-goods prices would rise when GDP rises if the supply curve for capital were upward-sloping (because the increase in GDP signals an increase in the demand for capital goods). ${ }^{14}$ The second column of Table 7 repeats this exercise, this time transforming the variables so that they are stationary prior to pooling the observations. In this case, the estimated coefficient on the tax variable is zero, and the residuals are much closer to white noise. This serial correlation is so decisive in the second test because the tax and capital-goods price variables are not co-integrated, while the cross-country capital-goods price series appear to be (although the short sample periods should make one wary of statements about cointegration).

Because the results in Table 6 revealed significant heterogeneity across assets, we repeat the comparison runs, asset by asset in Table 8 . The first column shows that the estimated tax coefficient is often negative and statistically

${ }^{14}$ Goolsbee also reports a negative estimated coefficient for GDP growth. 
Table 8: Investment Incentives and Capital-Goods Prices, US Asset Classes (Asset by Asset)

\begin{tabular}{|c|c|c|c|c|}
\hline & $\begin{array}{l}\text { Levels } \\
\text { Estimated } \\
\text { Coefficient } \\
\text { (standard error) } \\
\text { Durbin-Watson } \\
\text { statistic }\end{array}$ & $\begin{array}{l}\text { Differences } \\
\text { Estimated } \\
\text { Coefficient } \\
\text { (standard error) } \\
\text { Durbin-Watson } \\
\text { statistic }\end{array}$ & $\begin{array}{l}\text { Levels + AR(2) } \\
\text { Estimated } \\
\text { Coefficient } \\
\text { (standard error) }\end{array}$ & $\begin{array}{l}\text { Differences }+A R(2) \\
\text { Estimated } \\
\text { Coefficient } \\
\text { (standard error) }\end{array}$ \\
\hline Furniture & $\begin{array}{c}-0.05 \\
(0.09) \\
0.95\end{array}$ & $\begin{array}{c}0.18 \\
(0.10) \\
2.48\end{array}$ & $\begin{array}{c}-0.01 \\
(0.20)\end{array}$ & $\begin{array}{c}0.18 \\
(0.11)\end{array}$ \\
\hline Fabricated Metals & $\begin{array}{c}-0.37 \\
(0.11) \\
0.64\end{array}$ & $\begin{array}{c}-0.03 \\
(0.12) \\
1.62\end{array}$ & $\begin{array}{c}-0.29 \\
(0.11)\end{array}$ & $\begin{array}{c}-0.002 \\
(0.10)\end{array}$ \\
\hline Engines & $\begin{array}{c}-0.48 \\
(0.19) \\
0.87\end{array}$ & $\begin{array}{c}-0.02 \\
(0.14) \\
1.38\end{array}$ & $\begin{array}{l}-0.21 \\
(0.23)\end{array}$ & $\begin{array}{l}-0.15 \\
(0.17)\end{array}$ \\
\hline Tractors & $\begin{array}{c}-0.35 \\
(0.12) \\
1.21\end{array}$ & $\begin{array}{c}0.19 \\
(0.19) \\
2.38\end{array}$ & $\begin{array}{c}-0.25 \\
(0.17)\end{array}$ & $\begin{array}{c}0.29 \\
(0.19)\end{array}$ \\
\hline $\begin{array}{l}\text { Agricultural } \\
\text { Machinery }\end{array}$ & $\begin{array}{c}-0.42 \\
(0.11) \\
1.38\end{array}$ & $\begin{array}{c}0.11 \\
(0.13) \\
2.19\end{array}$ & $\begin{array}{c}-0.49 \\
(0.12)\end{array}$ & $\begin{array}{c}0.20 \\
(0.12)\end{array}$ \\
\hline $\begin{array}{l}\text { Construction } \\
\text { Machinery }\end{array}$ & $\begin{array}{c}-0.33 \\
(0.10) \\
0.95\end{array}$ & $\begin{array}{c}0.08 \\
(0.09) \\
1.25\end{array}$ & $\begin{array}{c}-0.01 \\
(0.14)\end{array}$ & $\begin{array}{c}0.10 \\
(0.10)\end{array}$ \\
\hline $\begin{array}{l}\text { Mining } \\
\text { Machinery }\end{array}$ & $\begin{array}{c}-0.82 \\
(0.19) \\
0.70\end{array}$ & $\begin{array}{c}-0.20 \\
(0.16) \\
1.23\end{array}$ & $\begin{array}{c}-0.29 \\
(0.51)\end{array}$ & $\begin{array}{l}-0.22 \\
(0.17)\end{array}$ \\
\hline $\begin{array}{l}\text { Metalwork } \\
\text { Machinery }\end{array}$ & $\begin{array}{c}-0.22 \\
(0.09) \\
0.99\end{array}$ & $\begin{array}{c}0.12 \\
(0.07) \\
1.55\end{array}$ & $\begin{array}{c}-0.004 \\
(0.08)\end{array}$ & $\begin{array}{c}0.17 \\
(0.11)\end{array}$ \\
\hline $\begin{array}{l}\text { Special Industrial } \\
\text { Machinery }\end{array}$ & $\begin{array}{c}-0.08 \\
(0.07) \\
0.87\end{array}$ & $\begin{array}{c}0.16 \\
(0.09) \\
1.64\end{array}$ & $\begin{array}{c}0.07 \\
(0.08)\end{array}$ & $\begin{array}{c}0.16 \\
(0.12)\end{array}$ \\
\hline $\begin{array}{l}\text { General Industrial } \\
\text { Machinery }\end{array}$ & $\begin{array}{c}-0.19 \\
(0.08) \\
0.79\end{array}$ & $\begin{array}{c}0.04 \\
(0.08) \\
0.89\end{array}$ & $\begin{array}{l}-0.05 \\
(0.10)\end{array}$ & $\begin{array}{c}0.04 \\
(0.07)\end{array}$ \\
\hline $\begin{array}{l}\text { Office and Computer } \\
\text { Machinery }\end{array}$ & $\begin{array}{c}-1.31 \\
(1.42) \\
0.23\end{array}$ & $\begin{array}{c}-0.04 \\
(0.44) \\
2.02\end{array}$ & $\begin{array}{c}0.14 \\
(0.41)\end{array}$ & $\begin{array}{c}-0.17 \\
(0.49)\end{array}$ \\
\hline $\begin{array}{l}\text { Service Industry } \\
\text { Machinery }\end{array}$ & $\begin{array}{c}-0.03 \\
(0.05) \\
1.19\end{array}$ & $\begin{array}{c}0.07 \\
(0.07) \\
1.98\end{array}$ & $\begin{array}{l}-0.06 \\
(0.05)\end{array}$ & $\begin{array}{c}0.08 \\
(0.09)\end{array}$ \\
\hline Electrical Distribution & $\begin{array}{c}-0.07 \\
(0.08) \\
0.58\end{array}$ & $\begin{array}{c}-0.06 \\
(0.08) \\
1.21\end{array}$ & $\begin{array}{l}-0.13 \\
(0.06)\end{array}$ & $\begin{array}{l}-0.08 \\
(0.09)\end{array}$ \\
\hline
\end{tabular}

Note: Standard errors are in parentheses 
Table 8: Continued

\begin{tabular}{|c|c|c|c|c|}
\hline & $\begin{array}{l}\text { Levels } \\
\text { Estimated } \\
\text { Coefficient } \\
\text { (standard error) } \\
\text { Durbin-Watson } \\
\text { statistic }\end{array}$ & $\begin{array}{l}\text { Differences } \\
\text { Estimated } \\
\text { Coefficient } \\
\text { (standard error) } \\
\text { Durbin-Watson } \\
\text { statistic }\end{array}$ & $\begin{array}{l}\text { Levels }+A R(2) \\
\text { Estimated } \\
\text { Coefficient } \\
\text { (standard error) }\end{array}$ & $\begin{array}{l}\text { Differences }+A R(2) \\
\text { Estimated } \\
\text { Coefficient } \\
\text { (standard error) }\end{array}$ \\
\hline Communication & $\begin{array}{c}0.21 \\
(0.10) \\
0.75\end{array}$ & $\begin{array}{c}-0.05 \\
(0.09) \\
0.93\end{array}$ & $\begin{array}{c}0.002 \\
(0.10)\end{array}$ & $\begin{array}{c}-0.02 \\
(0.09)\end{array}$ \\
\hline $\begin{array}{l}\text { Electrical } \\
\text { Equipment }\end{array}$ & $\begin{array}{c}-0.38 \\
(0.15) \\
0.65\end{array}$ & $\begin{array}{c}0.09 \\
(0.11) \\
2.10\end{array}$ & $\begin{array}{c}-0.21 \\
(0.14)\end{array}$ & $\begin{array}{c}0.09 \\
(0.14)\end{array}$ \\
\hline Trucks and Buses & $\begin{array}{c}0.08 \\
(0.22) \\
0.41\end{array}$ & $\begin{array}{c}0.08 \\
(0.17) \\
2.13\end{array}$ & $\begin{array}{c}-0.14 \\
(0.15)\end{array}$ & $\begin{array}{c}0.06 \\
(0.19)\end{array}$ \\
\hline Automobiles & $\begin{array}{c}0.62 \\
(0.11) \\
1.08\end{array}$ & $\begin{array}{c}0.33 \\
(0.17) \\
2.21\end{array}$ & $\begin{array}{c}0.31 \\
(0.17)\end{array}$ & $\begin{array}{c}0.40 \\
(0.19)\end{array}$ \\
\hline Aircraft & $\begin{array}{c}-0.38 \\
(0.10) \\
0.92\end{array}$ & $\begin{array}{c}-0.03 \\
(0.12) \\
2.13\end{array}$ & $\begin{array}{c}-0.15 \\
(0.15)\end{array}$ & $\begin{array}{c}0.06 \\
(0.12)\end{array}$ \\
\hline Ships & $\begin{array}{c}-0.23 \\
(0.11) \\
0.76\end{array}$ & $\begin{array}{c}0.02 \\
(0.10) \\
2.53\end{array}$ & $\begin{array}{c}-0.05 \\
(0.10)\end{array}$ & $\begin{array}{c}0.08 \\
(0.10)\end{array}$ \\
\hline Railway Equipment & $\begin{array}{c}-0.55 \\
(0.20) \\
0.43\end{array}$ & $\begin{array}{c}0.05 \\
(0.12) \\
1.32\end{array}$ & $\begin{array}{c}-0.01 \\
(0.10)\end{array}$ & $\begin{array}{c}0.04 \\
(0.11)\end{array}$ \\
\hline Instruments & $\begin{array}{c}0.02 \\
(0.14) \\
0.24\end{array}$ & $\begin{array}{c}0.11 \\
(0.07) \\
1.23\end{array}$ & $\begin{array}{c}0.15 \\
(0.06)\end{array}$ & $\begin{array}{c}0.14 \\
(0.08)\end{array}$ \\
\hline Other Equipment & $\begin{array}{c}-0.07 \\
(0.07) \\
0.92\end{array}$ & $\begin{array}{c}0.12 \\
(0.09) \\
1.82\end{array}$ & $\begin{array}{c}-0.002 \\
(0.07)\end{array}$ & $\begin{array}{c}0.16 \\
(0.11)\end{array}$ \\
\hline
\end{tabular}

Note: Standard errors are in parentheses

significant in level specifications, but that the Durbin-Watson statistics are often fairly close to zero. In differences, the Durbin-Watson statistics are close to 2 , and the estimated tax coefficients are nowhere negative and statistically significant. Column 3 repeats Goolsbee's specification in levels, this time allowing the $A R(2)$ correction to vary across assets. The estimated tax coefficient now looks quite similar to those from the first-differenced specifications. For completeness, the final column of Table 8 reports the results for the firstdifferenced specification with the $A R(2)$ correction. Again, the estimated tax coefficients are always zero. 
While we can reproduce Goolsbee's results with his data and specification, we conclude that one can only find a 'statistically significant' coefficient on the tax variable if one accounts inadequately for the high level of serial correlation in the variables and the absence of co-integration between taxes and prices. We use quotation marks in the previous sentence because the regressions' non-stationary errors make traditional critical values inapplicable. We do not believe that the asset-class data for the United States support the notion that investment incentives generate large short-run price increases for capital goods. The case is not yet closed; additional empirical work in this area should use more disaggregated data (for example, studying the response of stock prices of capital-goods-supplying firms to the announcement of investment incentives).

\section{Conclusion and Implications}

The results from our three sets of tests, employing different data sets, tell a consistent story. The price paid for capital goods in any one country in the world is approximately equal to the (common-currency) price paid in every other country, and this conclusion holds even if an individual country has adopted its tax policy to encourage investment locally. Moreover, this result holds even for the United States. This suggests that the effects of investment tax policy have not been muted by sharply upward-sloping supply schedules for capital goods, and that empirical work that assumes that each country is a price-taker in the world market for capital goods is relying on an assumption that is consistent with the broad patterns in the movements of international capital-goods prices. Given other evidence of strong demand responses to tax policy reviewed earlier, we conclude that investment incentives are likely to have potent short-run and long-run effects on fixed-capital formation. Moreover, for the data we examine, this result holds even for the United States. We should note, however, that recent investment research points out pitfalls in basing conclusions on evidence from time-series regressions such as those reported here. Endogeneity of policy and other problems create empirical difficulties, again making desirable empirical analysis of more disaggregated data.

Care must be taken in drawing inferences about the desirability of stimulative tax policy based on our results. For example, while our results are consistent with the hypothesis we have expressed many times ${ }^{15}$ that long-run changes in tax policy toward investment can be expected to have large and predictable

\footnotetext{
${ }^{15}$ See Cummins, Hassett and Hubbard 1994, 1996, and Hassett and Hubbard 1997.
} 
effects on investment, ${ }^{16}$ we do not mean to imply that temporary or uncertain incentives are desirable from a policy perspective. In particular, the fact that explicitly temporary incentives can have a large short-run impact on investment does not make them desirable policies per se. Because of uncertainty and the costs of adjusting the capital stock, we doubt that policy-makers can time investment incentives sufficiently well to carry out effective stabilization policy. In addition, the use of temporary incentives magnifies uncertainty in business capital budgeting, making it more difficult for companies to forecast the path of the user cost of capital.

Finally, our evidence does not necessarily imply that tax policy should be used to stimulate business investment. While it is instructive to ask how effective investment incentives are in increasing the fixed-capital stock, another important question remains - what is the social value of the increase in the fixed-capital stock? It is well known that competitive economies do not necessarily converge to the 'correct' capital stock. Our reading of the literature applying 'golden-rule' models and more general models of dynamic efficiency is that both capital-stock and cash-flow data for the United States suggest that, by increasing the stock of equipment capital, investment incentives have positive social returns. ${ }^{17}$ However, because existing analytical models for this purpose are derived for a closed economy, it is difficult to extend the comparison to domestic versus foreign fixed capital in much more open economies. We view this as an important topic for future research.

Professor Kevin Hassett

American Enterprise Institute

1150 Seventeenth Street, NW

Washington, DC 20036

USA

\section{References}

Auerbach, Alan J., and Kevin A. Hassett (1991), 'Recent US Investment Behavior and the Tax Reform Act of 1986: A Disaggregate View', Carnegie-Rochester Conference Series on Public Policy, 35, 185-215.

\footnotetext{
${ }^{16}$ More generally, we see no reason that other policy sources of investment stimulus would have large effects on prices of capital goods. For example, Cohen, Hassett and Hubbard 1998 argue that even modest reductions in the rate of inflation in countries with tax systems distorted by inflation can provide a potent long-run investment stimulus.

${ }^{17}$ See Hassett and Hubbard 1997. To the extent that equipment investment generates externalities in the growth process see DeLong and Summers 1991 this point holds a fortiori. Auerbach, Hassett and Oliner 1994 dispute the DeLong and Summers evidence on externalities.
} 
— Investment', Quarterly Journal of Economics, 109 (August), 789-802.

Bordo, Michael, and Ehsan Choudry (1976), 'The Behaviour of the Prices of Traded and Nontraded Goods: The Canadian Case, 1962-74', paper presented at the Southern Economic Association Annual Meetings, Atlanta, 19 October 1976.

Caballero, Ricardo, Eduardo M. R. A. Engel and John C. Haltiwanger (1995), 'Plantlevel Adjustment and Aggregate Investment Dynamics', Brookings Papers on Economic Activity, 2, 1-54.

Cohen, Darrel, Kevin A. Hassett and R. Glenn Hubbard (1998), 'Inflation, Taxes, and the User Cost of Capital,' in Martin Feldstein, ed., Benefits of Price Stability. Chicago: University of Chicago Press (forthcoming).

Cummins, Jason G., Trevor S. Harris and Kevin A. Hassett (1995), 'Accounting Standards, Information Flow, and Firm Investment Behavior', in Martin Feldstein, James R. Hines and R. Glenn Hubbard, eds, Effects of Taxation on Multinational Corporations. Chicago: University of Chicago Press.

Cummins, Jason G., Kevin A. Hassett and R. Glenn Hubbard (1994), 'A Reconsideration of Investment Behavior Using Tax Reforms as Natural Experiments', Brookings Papers on Economic Activity, 2, 1-74.

(1996), 'Tax Reforms and Investment: A Cross-Country Comparison', Journal of Public Economics, 62, 237-73.

DeLong, J. Bradford, and Lawrence H. Summers (1991), 'Equipment Spending and Economic Growth', Quarterly Journal of Economics, 106, 445-502.

Feldstein, Martin, and Charles Y. Horioka (1980), 'Domestic Savings and International Capital Flows,' Economic Journal , 90 (June), 314-29.

Frankel, Jeffrey A. (1991), 'Quantifying International Capital Mobility in the 1980s', in B. Douglas Bernheim and John B. Shoven, eds, National Saving and Economic Performance. Chicago: University of Chicago Press.

Goolsbee, Austan (1988), 'Investment Tax Incentives and the Price of Capital Goods,' Quarterly Journal of Economics, 113 (February), 121-48.

Hall, Robert E., and Dale W. Jorgenson (1967), 'Tax Policy and Investment Behavior,' American Economic Review, 57 (June), 391-414.

Hassett, Kevin A., and R. Glenn Hubbard (1997), 'Tax Policy and Investment', in Alan J. Auerbach, ed., Fiscal Policy: Lessons from Economic Research. Cambridge, Mass.: MIT Press.

Jorgenson, Dale W. (1963), 'Capital Theory and Investment Behavior', American Economic Review, 53, 247-59.

Kravis, Irving, and Robert Lipsey (1977), 'Export Prices and the Transmission of Inflation', American Economic Review, 67 (February 1978), 155-63.

- (1978), Price Competitiveness in World Trade. New York: Columbia University Press. 
(1997), 'Price Behavior in the Light of Balance of Payment Theories', Journal of International Economics, 8 (May), 193-246.

Officer, Lawrence (1986), 'The Law of One Price Cannot Be Rejected: Two Tests Based on the Tradable/Nontradable Goods Price Ratio', Journal of Macroeconomics, (Spring), 159-82.

Organization for Economic Cooperation and Development. National Income Accounts, various issues. 